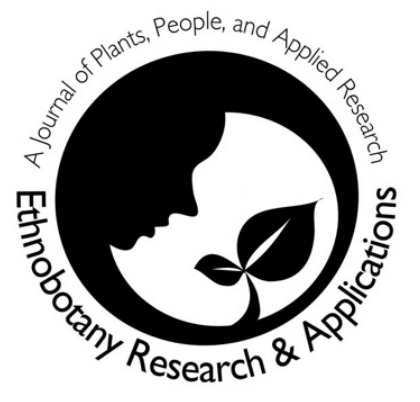

\title{
Triplochiton scleroxylon K. Schum (Malvaceae- Sterculioideae): a key species of the Oro worship in Benin
}

\author{
Gabin Ganka and Adandé Belarmain Fandohan
}

\section{Correspondence}

Gabin Ganka* and Adandé Belarmain Fandohan

Unité de Recherche en Foresterie et Conservation des Bioressources, Laboratoire de Sciences Végétales, Horticoles et Forestières, Ecole de Foresterie Tropicale, Université Nationale d'Agriculture, BP 43, Kétou, Bénin.

*Corresponding Author: gabinganka@gmail.com

Ethnobotany Research \& Applications 22:43 (2021)

\section{Research}

Background: The African whitewood (Triplochiton scleroxylon), is a sacred and revered species in the tradition of the Oro cult in Benin. The species' natural stands are in decline and are confined to sacred forests owned by Oro secret societies. Information on its cultural uses and significance in the tradition of the Oro cult is however, poorly documented. The objective of this study is to assess the cultural keystone status of the species in the tradition of Oro worship in Benin.

Method: One hundred and twenty-five members of the secret society of the cult were investigated on the names and meanings of all the species used in this tradition. Six (06) identification indices of key cultural species were used for this purpose: the importance and use value of the species, their value as an additional source of income, their psycho-socio-cultural function, their ethno-taxonomic diversity and their degree of irreplaceability. Cultural keystone status scores were estimated and various statistical tests were performed to examine their variation and correlation with the calculated indices.

Results. Ten specific uses of the African whitewood were reported; of which the top three were all of spiritual and ritual importance. Key cultural species indicators showed a high value of T. scleroxylon for the tradition of "Oro" worship in Benin.

Conclusion: Triplochiton scleroxylon is a cultural keystone species for the Oro cult in Benin. It would be interesting to examine the potential impact of the decline of this species on the identity and stability of the Oro cult.

Keywords: African whitewood tree, key cultural species, bio cultural diversity, Benin.

\section{Resumé}

Contexte et objectif. Le Samba (Triplochiton scleroxylon), est une espèce sacrée et vénérée dans la tradition du culte Oro au Bénin. Les peuplements naturels de l'espèce sont en déclin et se réduisent de plus en plus aux forêts sacrées du culte Oro. Les informations sur ses usages et son importance culturels dans la tradition du culte Oro sont toutefois peu documentées. L'objectif de cette étude est d'évaluer le statut de clé de voûte cultuel de l'espèce dans la tradition du culte Oro au Bénin.

Méthode: Cent vingt-cinq membres de la société secrète du culte ont été enquêtés sur les noms et significations de toutes les essences utilisées dans cette tradition. Six (06) indices d'identification d'espèces culturelles clés ont été utilisés à cet effet. Il s'agit de : l'importance et la valeur d'usage des espèces, leur valeur en tant que source 
additionnelle de revenu, leur fonction psycho-socio-culturelle, leur diversité ethno-taxonomique et leur degré d'irremplaçabilité. Les scores du statut clé de voûte culturelle ont été estimés et divers tests statistiques ont été réalisés pour examiner leur variation et corrélation avec les indices calculés.

Résultats: Les indicateurs d'espèce culturelle clé ont montré dans le contexte culturel actuel et historique du Bénin, de fortes valeurs de T. scleroxylon pour la tradition du culte « Oro».

Conclusio: Triplochiton scleroxylon est une clé de voûte culturelle du culte Oro au Bénin. Il serait intéressant d'examiner l'impact potentiel du déclin de cette espèce sur l'identité, la stabilité, et la perpétuité du culte Oro.

Mots clés. Samba, espèce culturelle clé, diversité bioculturelle, Bénin.

\section{Background}

The wide savannah corridor that reaches the coast of southern Ghana, Benin, and Togo, separates the African rainforest into two blocks: the Central African block and the West African block. This corridor is called Dahomey Gap and, in these areas, savannahs extend to the coast of the Gulf of Guinea. This area is characterized by low rainfall and while in the West African rainforest over $2000 \mathrm{~mm}$ of rainfall per year fall, only $1200-1000 \mathrm{~mm}$ per year fall in this in this corridor (Salzmann \& Hoelzmann, 2005). However, the presence of isolated stands of rainforest, most of which are sacred forests (Akoègninou 1998), proves that climate is not the only factor in the existence of this corridor. The existence of the Dahomey Gap can be attributed to two main factors: climate on the one hand and anthropogenic influence on the other. In the face of continuously growing anthropogenic pressure and agricultural practices that challenge the ecosystem balance in this corridor, sacred forests constitute important remaining fragments of forests (Kokou \& Sokpon 2006). Indeed, sacred forests have existed for a very long time in Africa (Koukou \& Sokpon, 2006). These are patches of forest in which there are remnants of an ancient continuous forest along the entire West African coast (Fairhead $\&$ Leach, 1998). They are numerous small vegetation formations ranging from a few acres to 40 hectares in size, essentially sacred and variable in socio-cultural, political, physiognomic, ethnic, and geomantic terms (Kokou \& Sokpon, 2006). The exceptional cultural diversity due to the multiplicity of ceremonies and rituals practiced in these ecosystems is fundamentally important for the cultural identity of the populations of these countries (Kokou \& Sokpon, 2006). These ecosystems represent places of residence of the ancestors and protective gods of local communities. In Benin, there are sacred forests that cover a significant area. These sacred forests play a considerable socio-cultural and ecological role, sometimes sheltering species or water sources on which the existence of an entire deity or ancestral tradition depends. Local communities therefore establish rules, which vary from region to region, including a ban on the uncontrolled harvesting of firewood and plant organs for medicinal purposes (although these rules allow for the exploitation of firewood and medicinal plants). This mitigates overexploitation of natural resources and preserves sites and their biodiversity over generations (Ceperley et al. 2010). The work of Kokou \& Sokpon, (2006) has shown that the erosion of cults or traditions could diminish the conservation value of sacred forests and thus of West African biodiversity.

Although many life forms contribute in a way to human survival, some species have more direct relevance to humans and are of prime importance in their cultures (Garibaldi $\&$ Turner 2004). These are the key cultural species. These species play special roles in communities as part of cultural support, food, shelter, fuel, and medicine suppliers; and thus, benefit from conservation efforts in traditional systems (Christancho \& Vining 2004; Garibaldi \& Turner 2004; McCarthy et al. 2014;). Culturally important species can shape the cultural identity of a particular socio-cultural group in major ways (Garibaldi \& Turner 2004). Such species reunite conservation/restoration and cultural concerns and result in an upward spiral of increasing effectiveness in maintaining and restoring human and ecosystem health. So, researchers must turn their attention to the evaluation of the cultural keystone status of plant and animal species. The identification and appreciation of the complex relationships of cultural keystone species with each other and with their habitats can contribute to conservation, domestication, and ecosystem restoration efforts (Cristancho \& Vining 2004; Garibaldi \& Turner, 2004). Since communities that identify with cultural keystone species develop a strong desire to conserve them (Garibaldi \& Turner, 2004), their identification should serve as the basis for any effort to preserve and restore biocultural or socio-ecological systems (Cristancho \& Vining 2004; Garibaldi \& Turner, 2004; Sujarwo et al. 2019; Coe \& Gaoue 2020a).The identification of key species in each community's culture can therefore be very useful for conservation and domestication programs. One of the main benefits of the identification of cultural keystone species is that they provide an effective starting point for the conservation and restoration of socio-ecological systems (Cristancho \& Vining 2004; Garibaldi \& Turner 2004). 
Several researchers have defined cultural keystone species based on qualitative data (Christancho \& Vining 2004; McCarthy et al. 2014). As for ecological keystone species, their identification has been proved difficult. Christancho \& Vining (2004), argue that a species can have the status of cultural keystone species when it fulfills most of the following criteria: the history of its origin is linked to myths, ancestors or the origin of culture, it is at the heart of the transmission of knowledge, it is essential in rituals on which the stability of the community depends, it is used to meet the basic community needs such as food, shelters, curing diseases, it has significant spiritual or religious value, it physically exists in or near the territory of the cultural group and the cultural group designates the species as one of the most important species. However, based on their qualitative and complex nature, cultural keystone species can be identified using a quantitative method based on six indicators of cultural influence: the physical presence of the species; the type, intensity and multiplicity of its use; the ethno-taxonomic diversity of the species' names in the community; the psycho-social function (i.e., the role of the species in the stories, ceremonies or symbolism of the socio-cultural group, the persistence and memory of the species' use in relation to cultural change); the level of uniqueness position of the species in the culture (difficult to substitute with other available native species) and the extent to which it provides opportunities from outside the territory (Garibaldi \& Turner 2004). It is unclear what these approaches can achieve in terms of reproducibility, global syntheses, and application in Conservation Biology. Nevertheless, the work of Coe \& Gaoué (2020a; 2020b) has proposed a quantitative approach that integrates all the species used by a community and ultimately identifies the cultural keystone species of that community. Still, thoughts, beliefs, myths, and institutions made manifest by the myriad of African culture and tradition are particular. A cult or deity may be intimately linked to a single species in such a way that the species becomes the essence of the deity and thus the tradition. Besides, because there is no prior study on the cultural keystone status of species in Africa, the approach developed did not consider the African ethnosphere. However, given the objectivity of the approach used by Coe \& Gaoue (2020b), it can be adapted to assess the keystone status of the sacred and venerated species, in Africa. The African whitewood, Sambawawa or Samba (Triplochiton scleroxylon, Sterculioideae) is among the most revered sacred species in Benin (Kokou \& Sokpon 2006). It is used to make monoxylean dugouts, carved objects, mortars, and drums. A sacred tree of the "Oro" of the Nagot-yoruba in southern Benin (Palla \& Louppe 2002; Kokou \& Sokpon 2006; Adomou et al. 2011), its' distribution area is increasingly being confined to the sacred forests of Oro. Oro is a god of ancestral spirits among the Nagot-Yoruba ethnolinguistic groups of Benin and Nigeria (Akanji \& Dada 2012). They are dead spirits that wander in the air and must be appeased by certain sacrifices. Oro is a source of power and authority. It is an institution that performs political, judicial, and religious functions among the Nagot-Yoruba peoples. It is used for social purposes, and to preserve order in private and community life. Its cult is patriarchal by nature and held by male secret societies although orality mentions a major role of a woman at its origins (Akanji \& Dada 2012). This organization that is not open to women and ordinary men in society (Akanji \& Dada 2012). Thus, as of today, in Benin and Nigeria, females and non-members must stay indoors during its festivals as tradition forbids women and non-participants to see Oro. In Oro rituals and traditions, a species of the Malvaceae-Sterculioideae taxon (Triplochiton scleroxylon) is often mentioned: Triplochiton scleroxylon. Triplochiton scleroxylon is one of the most revered sacred species among the Oro in Benin. It is used in almost all ritual ceremonies of the cult. Given the seemingly real importance of $T$. scleroxylon, this piece of work aimed to assess whether it is a keystone species to the cult Oro or not. To this end, an approach adapted from Coe \& Gaoué (2020b) was used.

\section{Materials and Methods Study environment}

The study was conducted in Benin in the Guinean-Congolian center of endemism of plants' (Fig.1). The GuineanCongolian region is located in the southern part of Benin $\left(6^{\circ} 25^{\prime} \mathrm{N}\right.$ to $7^{\circ} 30^{\prime} \mathrm{N}$ ), with a sub-equatorial climate (Adomou 2005). Within that region, the Phytodistrict of Pobè and Plateau represent the main homeland of the Nagot-Yoruba sociocultural group, which is the heart of the "Oro" cult tradition (Fig. 1).

\section{Sampling and data collection}

An exploration phase was conducted to identify the sacred forests of the Oro cult in the study area as well as all the convents and members of that cult (Fig. 2).

At the end of the exploratory study, permission was sought from the village chief and the Adjana (chief dignitary of Oro) of each study site before the conduct of the surveys following in accordance with the code of ethics established by the International Society of Ethnobiology (ISE 2006). Respondents were identified and their permission was also obtained with the help of the local authorities before the administration of the interview guide designed for this purpose. 


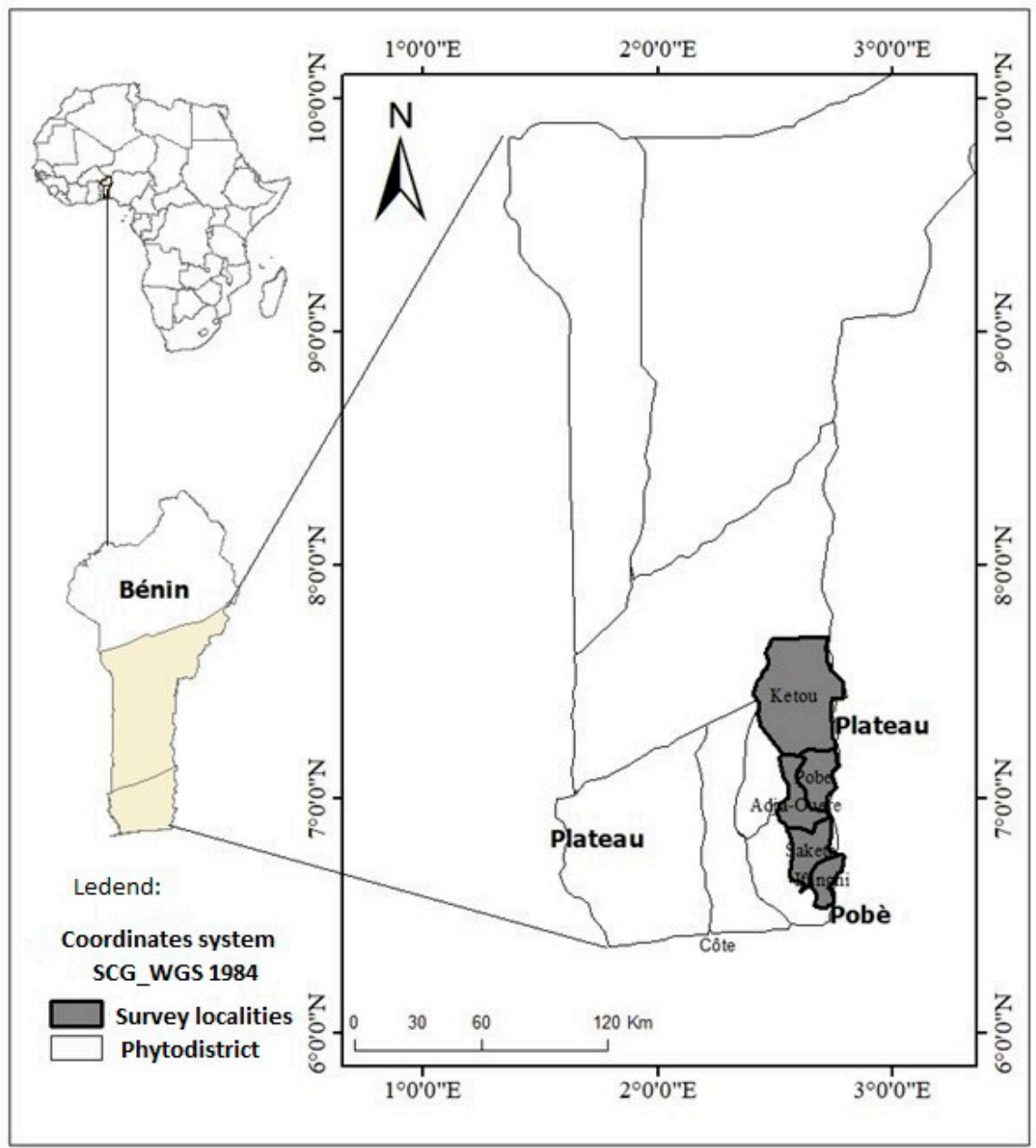

Figure 1. Distribution of the localities of the sacred forests of the Oro cult in Benin.

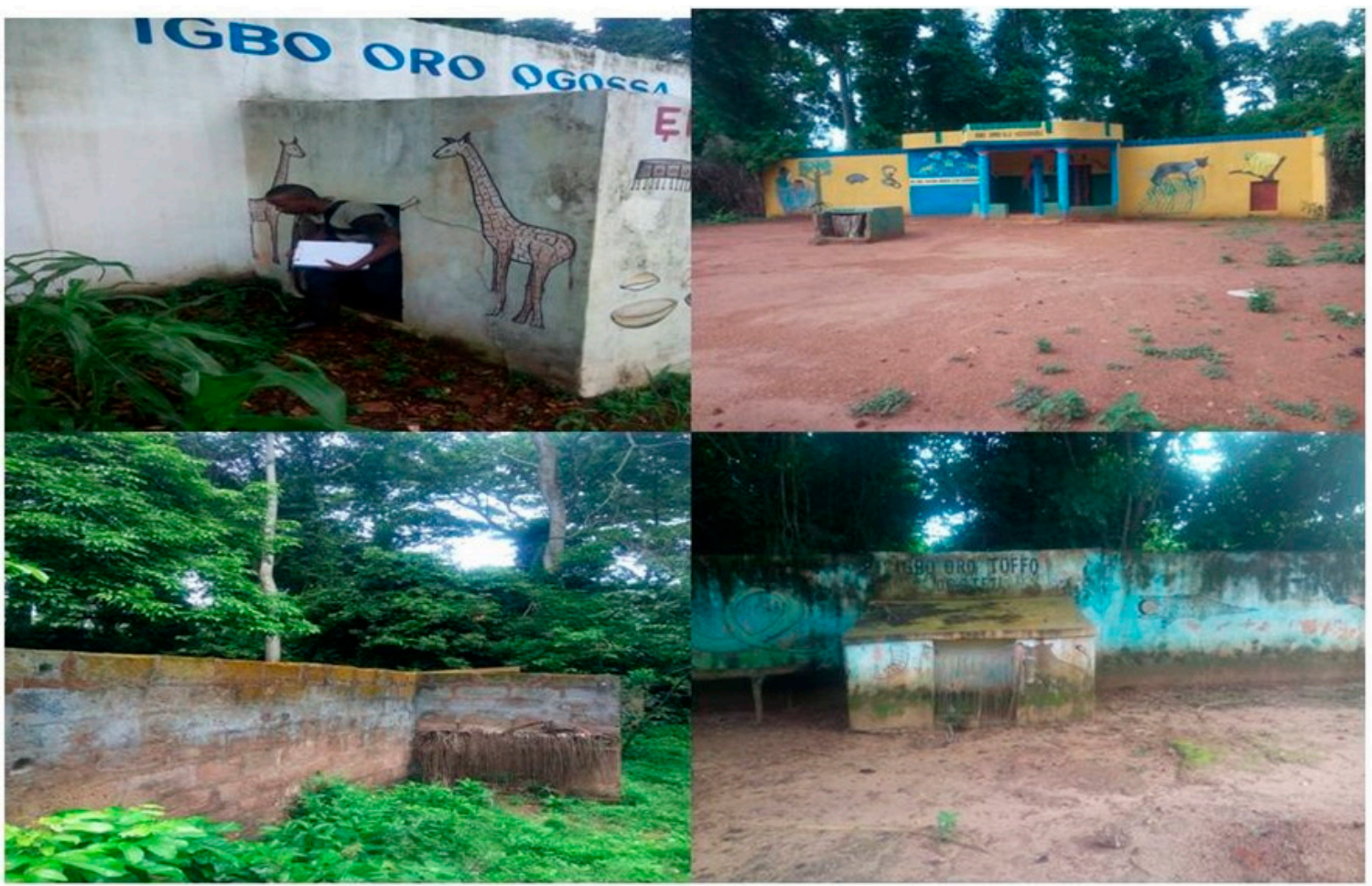

Figure 2. Some sacred forest convents of the Oro fetish in Benin. 
Considering the distribution of $T$. scleroxylon and its sacredness in Benin, we employed a non-random sampling approach using the snowball technique (Cochran 1977) was adopted to identify key informants among the followers and dignitaries of the Oro cult sacred forests. This technique consists of approaching a competent informant for the study, who after being interviewed, in turn points to another competent person from the same community and the process evolves until all competent persons for the subject of study are interviewed. It allowed us to directly approach informants who are knowledgeable about $T$. scleroxylon in their community. The estimate of the number of key informants was considered representative when the saturation limit (the point at which no more informants are mentioned by the last respondent) was reached at the end of the survey (Cochran 1977). Information was recorded according to the rank and responsibility of the respondents in the cult. The baseline questionnaire was structured around knowledge of the role and use of all the species involved in different levels of the Oro cult ceremony.

\section{Ethnobotanical survey}

The ethnobotanical survey targeted the Oro cult members. Data were collected through semi-structured individual interviews and direct observations in the field. Information collected included names and meanings of all the species involved in the Orocult tradition, the various usages, and the rituals related to each species, the possibilities of substitution of each species or organ of the species considered to fulfil the same cultic function, its frequency of use, its use in trade and its psycho-social functions. The basic questionnaire was structured in two parts: (i) identity of the respondent, (ii) knowledge and names of the species in the different local languages, various usages and usage forms per plant part, and the rituals related to the species. Information gathered include the level of responsibility of the informant in the worship, the different criteria for identifying the species, which are key cultural elements, i.e., the physical presence of the species, their use value and level of importance, the extent to which they are used as an income source, their psycho-socio-cultural function, the ethno-taxonomic diversity, and the unique position of each species for the success of ceremonies and rituals of the Oro cult.

\section{Data processing and analysis}

A total of five (05) species - Newbouldia laevis P. Beauv., Uvariopsis tripetala Baker F., Euphorbia unispina NE Br., Adansonia digitata $\mathrm{L}$. and Triplochiton scleroxylon K. Shum - were identified for worship usages of the Oro cult. Relative citation frequency (RFC) of the cultural keystone species indicators (Garibaldi \& Turner 2004) was calculated for each species. High values of the RFC for a specific use reflect a consensus for that use of the species in the community. Uses reported by more than $20 \%$ of respondents were considered to reflect consensus (TRAMIL 1989). Knowledge reported by less than $20 \%$ of respondents may also be important in some socio-cultural groups. However, plants with a RFC of less than 5\% (Gouwakinnou et al. 2011) and which are substitutable in their role in the Oro cult tradition were not considered important to the tradition and were removed from the analyses. Thus, of the five (05) species identified, four (04) were removed from the analyses since they recorded only one specific usage. Indeed, $N$. laevis and $U$. tripetala are respectively used for only purification and snuff for corrections, in case of disrespect of traditional rules. As far as $A$. digitata and $E$. unispina are concerned, the only worship function they are requested for in the Oro cult can be achieved by $T$. scleroxylon. Thus, only $T$. scleroxylon was considered for analysis in the rest of the study.

\section{Use value of the species and the level of high importance of the species}

Ethnobotanical indices such as relative frequencies of citation (RFC), whole plant use value (VUT), organ use value (VUorg) of the species according to the respondents were used for the data analysis.

\section{Use value}

The total use value of the species in the Oro cult tradition ( $\left.\mathrm{VU}_{\mathrm{T}}\right)$ was expressed in terms of the average number of reported uses (Gomez-Beloz 2002). It was calculated by the formula:

$$
V U_{T}=\frac{\sum_{i=1}^{N} U R_{i}}{N}
$$

URi the number of specific uses reported by a respondent $i$ in the community and $\mathrm{N}$ the total number of respondents in the community. The knowledge according to the levels of responsibility of the Oro cult actors was examined using $\mathrm{VU}_{\mathrm{T}}$.

The use value per organ (VUorg) expresses the average number of uses per respondent. It was calculated using the formula: 


$$
V U_{\text {org }}=\frac{\sum_{i=1}^{N} U R_{\text {Org }, i}}{N}
$$

URorgi is the number of usages mentioned per organ by respondent $i$ and $\mathrm{N}$ the total number of respondents in the community.

\section{Measure of external resource acquisition.}

To assess the extent to which T. scleroxylon is used as an additional source of income, we asked each respondent whether products from $T$. scleroxylon were sold. The responses obtained were recorded as binary data $(0 ; 1)(\mathrm{Coe}$ \& Gaoué 2020b).

\section{Psycho-socio-cultural function of the species}

To assess the psycho-socio-cultural function of T. scleroxylon, we addressed the following questions to each informant: Does T. scleroxylon have a story related to the Oro cult? Does it participate in a worship ritual? Is there a spiritual dimension associated with its use in the cult? All responses were recorded as binary data $(0 ; 1)$.

\section{Measurement of ethno-taxonomic diversity of species names.}

The ethno-taxonomic diversity of T. scleroxylon was estimated with the Pielou's equitability index:

$$
R=\frac{\sum p i * \log 2(p i)}{\log 2(n)}
$$

$\mathrm{pi}$ is the proportion of the number of people mentioning a given local name $i$ and the total number of respondents mentioning a name for the species; $\mathrm{n}$ is the total number's names of the species in the tradition

\section{Unique position of T. scleroxylon in the Oro cult tradition}

We evaluated the unique position of the species using the irreplaceability index in specific uses or functions of the species. It was estimated as the average of the irreplaceability indices of all the plants' organs used. The irreplaceability index of each organ was calculated as the quotient of the total number of species of which part(s) can replace a given specific use or function of the species; and the total number of species listed divided by the total number of specific uses of the organ considered (Coe \& Gaoue 2020b).

\section{Estimating the cultural keystone status score}

In order to estimate the cultural keystone status score of the species, a principal component analysis (PCA) was performed on the predictors of T. scleroxylon cultural keystone status and the organs of the species. Statistical analyses were performed in R software, version 4.0.3 (R Core Team 2020). The PCA was carried out with the "FactoMineR" package (Lê et al., 2008). The graphical representations were made with the "factoextra" packages (Kassambara \& Mundt, 2020) for the biplot. The variables used for the PCA included five indices: use value, ethnotaxonomic diversity, psycho-social function, irreplaceability, and external resource acquisition. Principal components representing a unique combination of these predictors were generated. Each principal component provides a score per species organ. The first set of principal components that explained more than $50 \%$ of the variance information in the data was retained. The cultural keystone status score of the species was the product of the retained principal component scores for each Organ (Coe \& Gaoue 2020a). To identify indices that significantly predicted the cultural keystone status of T. scleroxylon, scatter plots of the predictor matrices were made with bivariate scatter plots below the diagonal, histograms on the diagonal and Spearman's correlations by predictor pairs above the diagonal.

\section{Results}

Assessment of the cultural keystone status of $T$. scleroxylon Use value of the species and the high level of importance of the species The respondents mentioned 10 specific uses of Triplochiton scleroxylon reveals in the Oro tradition. The use of the species for making spirit protection statuettes (97.35\%), its leaves pruning by the Oro (97.35\%), and its use in initiation and protection ceremonies (94.70\%) are the most prominent reported uses. 


\section{Cultural/worship uses}

They are overall 07 stages of Oro rituals or cult events, all requiring the use of Triplochiton scleroxylon. Knowledge about the use of the species in the different ceremonies and rituals of the Oro cult does not vary significantly according to the level of responsibility (rank) of the cult actors (Fig. 3).

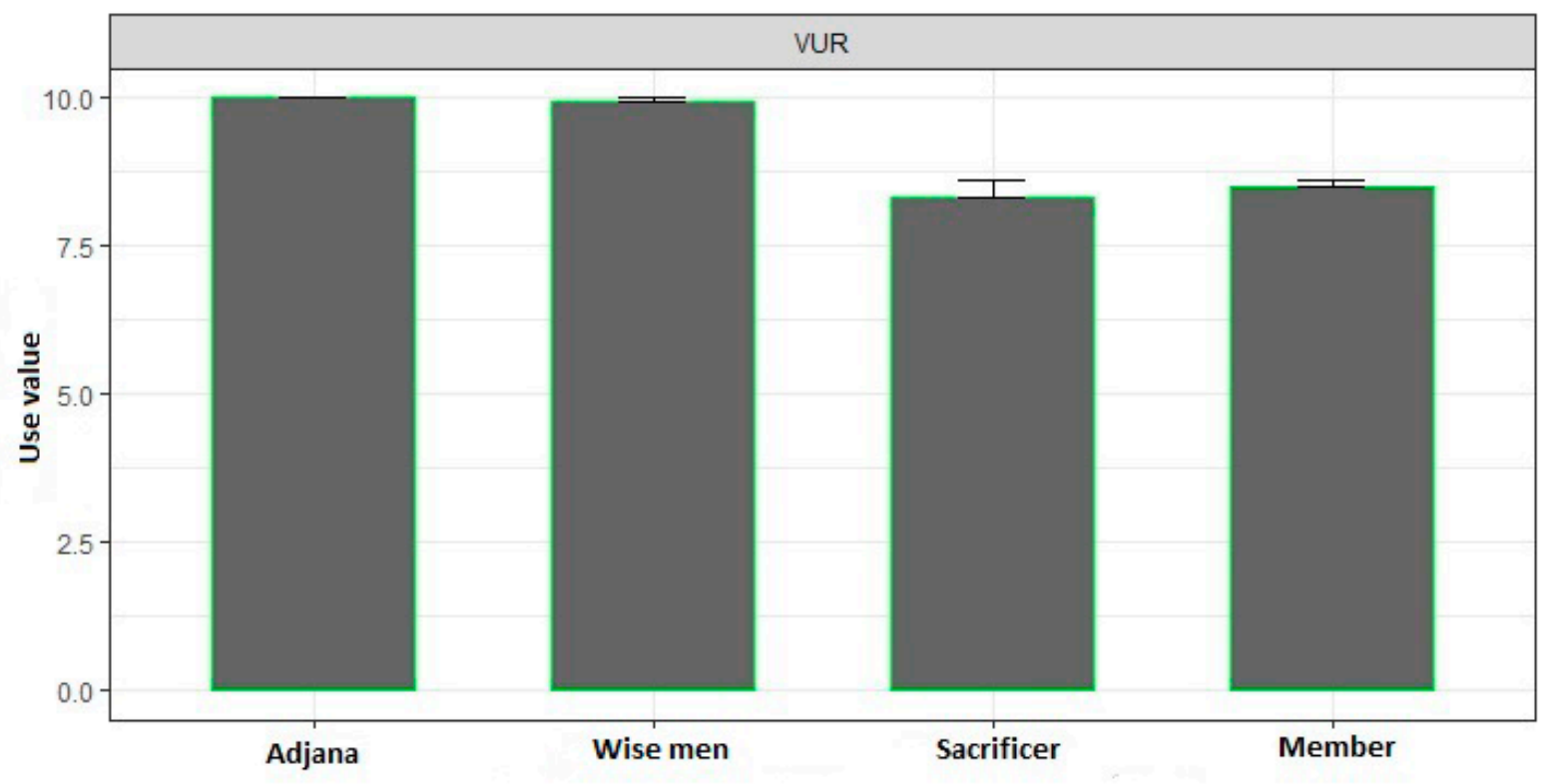

Figure 3. Cult use value of $T$. scleroxylon according to the actors of the Oro cult.

The uses of T. scleroxylon in the ceremonies and rituals of the Oro cult vary according to the parts of the plant (Fig. 4). The most commonly used organs are leaves (Oro exit ceremony and pruning), roots (Oro exit ceremony and making of the sacred Oro drums) and the trunk (sculpture of spirit protection statuettes and sacred and non-sacred drums, shelf and sawdust used to draw /fa divination signs, and timber for sale).
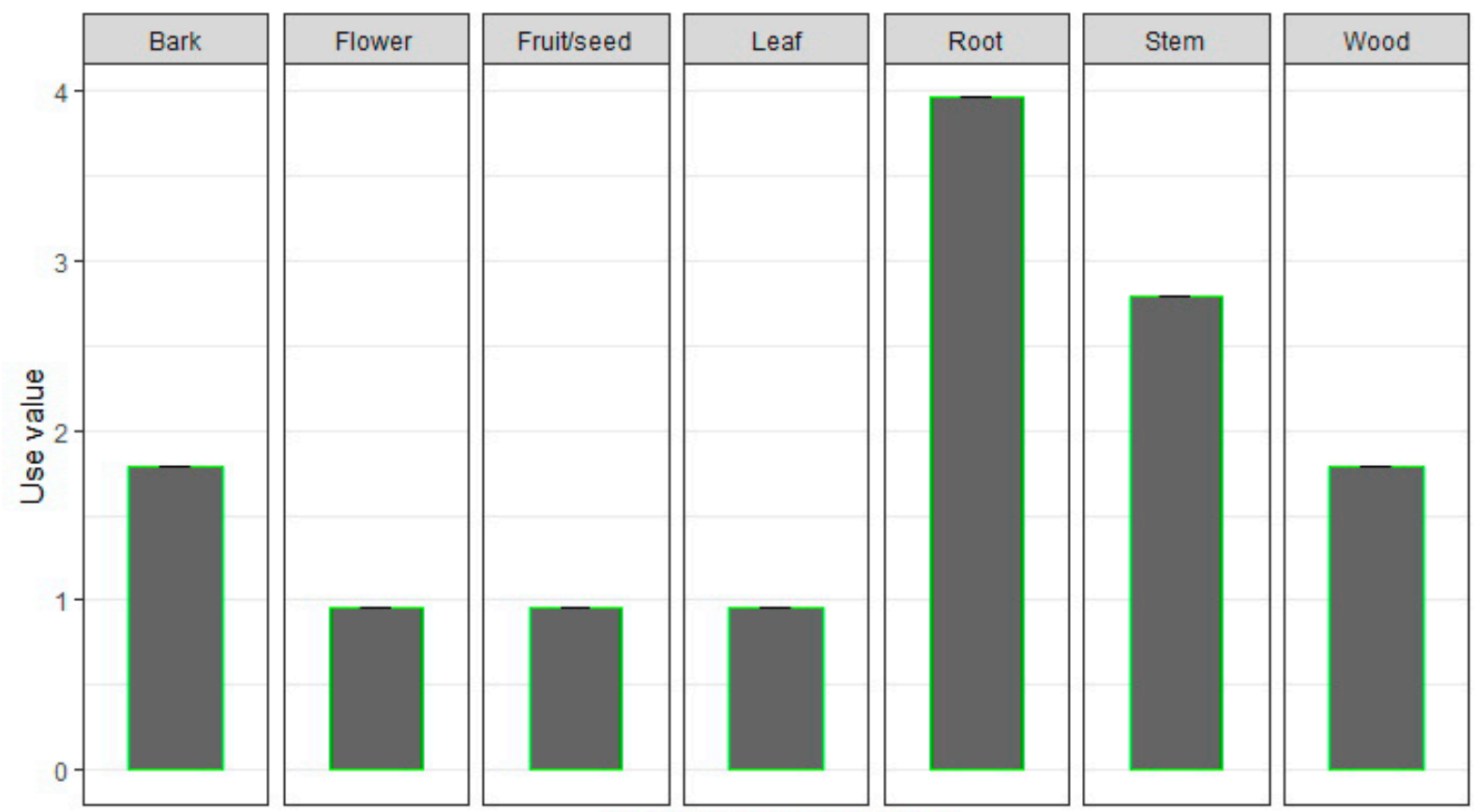

Organ from T. scleroxylon

Figure 4. Cult use value of T. scleroxylon organs. 
Ethno-taxonomic diversity of $\boldsymbol{T}$. scleroxylon

In the Oro cult tradition, several names are used to refer to T. scleroxylon. These are Aréré, Egui aréré, Egui Oro or Egui Ogù. The value of the Pielou equitability computed was 0.6, suggesting a relative predominance of a few names over the other designations within the Oro cult community. The name "Aréré or Egui aréré" seemed to be the most used by the actors of the Oro cult tradition in Benin.

\section{Psycho-socio-cultural function of the species}

All the respondents claimed that T. scleroxylon is historically linked to the Oro, and that no Oro story can be told without mentioning it. According to the interviewees, the Oro was revealed to a woodcutter when he felled a $T$. scleroxylon tree. After a consultation with the Fâ or Ifa (art of divination), it was recommended to house it within the T. scleroxylon feet, hence the name 'Egui Oro'. The species is intimately and historically linked to the Oro cult.

Table 1. Role of the organs of T. scleroxylon in the Oro cult tradition in Benin.

\begin{tabular}{|l|l|}
\hline Organ from T. scleroxylon & Role \\
\hline Leaf & $\begin{array}{l}\text { Leaf pruning by the Oro fetish, fetish exit ceremony, feeding and other ritual } \\
\text { ceremonies. }\end{array}$ \\
\hline Flower/ Fruit/seed & Leaf pruning by the Oro fetish \\
\hline Stem & $\begin{array}{l}\text { Guide, manufacture of statuette of spiritual protection and other ritual } \\
\text { ceremonies }\end{array}$ \\
\hline Wood & $\begin{array}{l}\text { Habitat of the fetish, manufacture of statuette of spiritual protection, sacred tam- } \\
\text { tam fetish Oro and not sacred, divinatory art and other ritual ceremonies }\end{array}$ \\
\hline Root & $\begin{array}{l}\text { Manufacture of the Oro sacred drum fetish, spiritual protection and other ritual } \\
\text { ceremonies }\end{array}$ \\
\hline Bark & Spiritual protection and other ritual ceremonies \\
\hline
\end{tabular}

\section{Persistence and memory of the use of $T$. scleroxylon in relation to cultural change}

All the respondents affirmed that at the origin of the Oro cult, T. scleroxylon was used in all the ritual ceremonies of the Oro cult. It is the tree that is used to represent the Oro, hence its name "Egui Oro" in the Nagot dialect.

\section{Extent to which T. scleroxylon provides additional income sources}

All the respondents claimed that $T$. scleroxylon is a species with high economic value not only to the Orocult actors but also to the entire local community in its distribution area.

The trading of T. scleroxylon timber is reported to follow well-established rules in the convents. Periodic inventories are initiated to identify adult plants of the species. These plants are felled (Fig. 5) and cleared from the forests to be sold first to forestry operators who are followers of the Oro cult and then resold to non-adherents. Resources from the sale of the species are used to cover the costs of annual ceremonies and rituals and the maintenance of the Oro deity's shelters (Fig. 2).

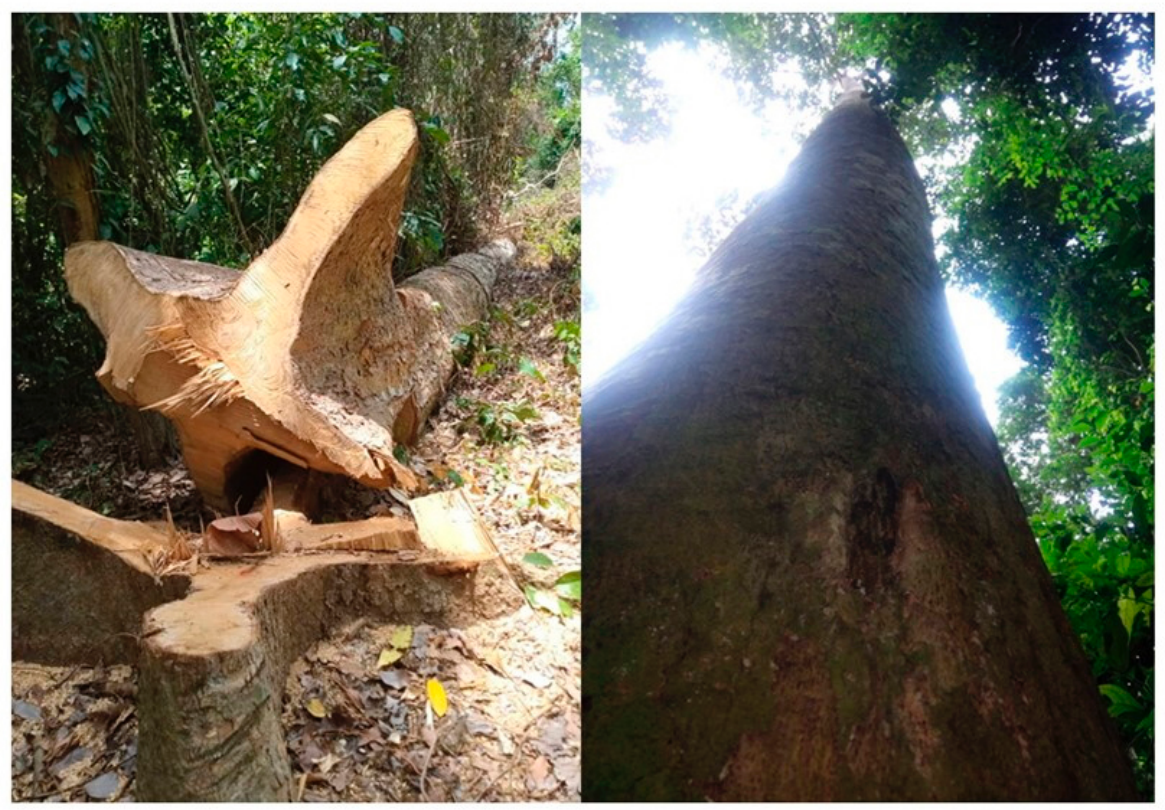

Figure 5. Triplochiton scleroxylon felled in the sacred forest of Itchèrè-Toffo. 


\section{Unique position status of $T$. scleroxylon}

The value of the irreplaceability index $(\mathrm{I}=0)$ of certain plant parts in the ceremonies and rituals of the Oro cult illustrated the unique position of $T$. scleroxylon (Table 2).

Table 2. Irreplaceability index of the organs of T. scleroxylon.

\begin{tabular}{|l|l|l|l|l|l|l|}
\hline Organ from T. scleroxylon & Leaf & Flower/Fruit/seed & Stem & Wood & Root & Bark \\
\hline Irreplaceability index (I) & 0.2 & 0.88 & 0 & 0 & 0 & 0 \\
\hline
\end{tabular}

Reason for the irreplaceability of $T$. scleroxylon in Oro cult events

There are several reasons why, according to the actors of the Oro community, T. scleroxylon has a unique and irreplaceable position in Oro cult manifestations in Benin (Table 3).

Table 3. Reasons for the irreplaceability of T. scleroxylon in the ceremonies of the Oro cult.

\begin{tabular}{|l|l|l|l|l|}
\hline Reason 1 & Reason 2 & Reason 3 & Reason 4 & Reason 5 \\
\hline Oro sacred fetish & Omnipresence in & $\begin{array}{l}\text { Irreplaceability of } \\
\text { tree }\end{array}$ & $\begin{array}{l}\text { Irreplaceability of } T . \\
\text { scleroxylon in }\end{array}$ & $\begin{array}{l}\text { Irreplaceability of } T . \\
\text { scleroxylon in major } \\
\text { emblems/symbols }\end{array}$ \\
\hline
\end{tabular}

The reasons for the irreplaceability of the species in cultural and/or cultic manifestations (Table 3) of the Oro cult, vary according to the actors of the Oro community. For the Adjana (in charge of the convents) and the wise men, T. scleroxylon incarnates or symbolizes in itself the Oro.

\section{Perception of the Oro cult actors on the unique role of $\boldsymbol{T}$. scleroxylon in the cult's manifestations}

The Correspondence Factorial Analysis (CFA) carried out on the reasons why T. scleroxylon occupies a unique and irreplaceable place in the Oro cult manifestations according to the actors of the Oro community showed that the first two factorial axes synthesize all the information collected (contain $95.76 \%$ of collected information; Fig. 4). The projection of the reasons for the irreplaceability of T. scleroxylon in the Oro cult events and the actor groups of the Oro cult community on the two factorial axes indicates that the Adjana believe that reason 3 (Irreplaceability of $T$. scleroxylon in stories) and reason 5 (Irreplaceability of $T$. scleroxylon in major emblems/symbols) explain the irreplaceable role of T. scleroxylon in the Oro cult ceremonies. According to the community priests, Reason 1 (Oro sacred tree) explains why no other species will be able to replace T. scleroxylon in the ritual ceremonies of the Oro cult. The wise men and other community members believe that Reason 2 (Omnipresence in the collective consciousness) and Reason 4 (Irreplaceability of $T$. scleroxylon in ceremonies) explain the unique position of $T$. scleroxylon in Oro cult ceremonies (Fig. 6).

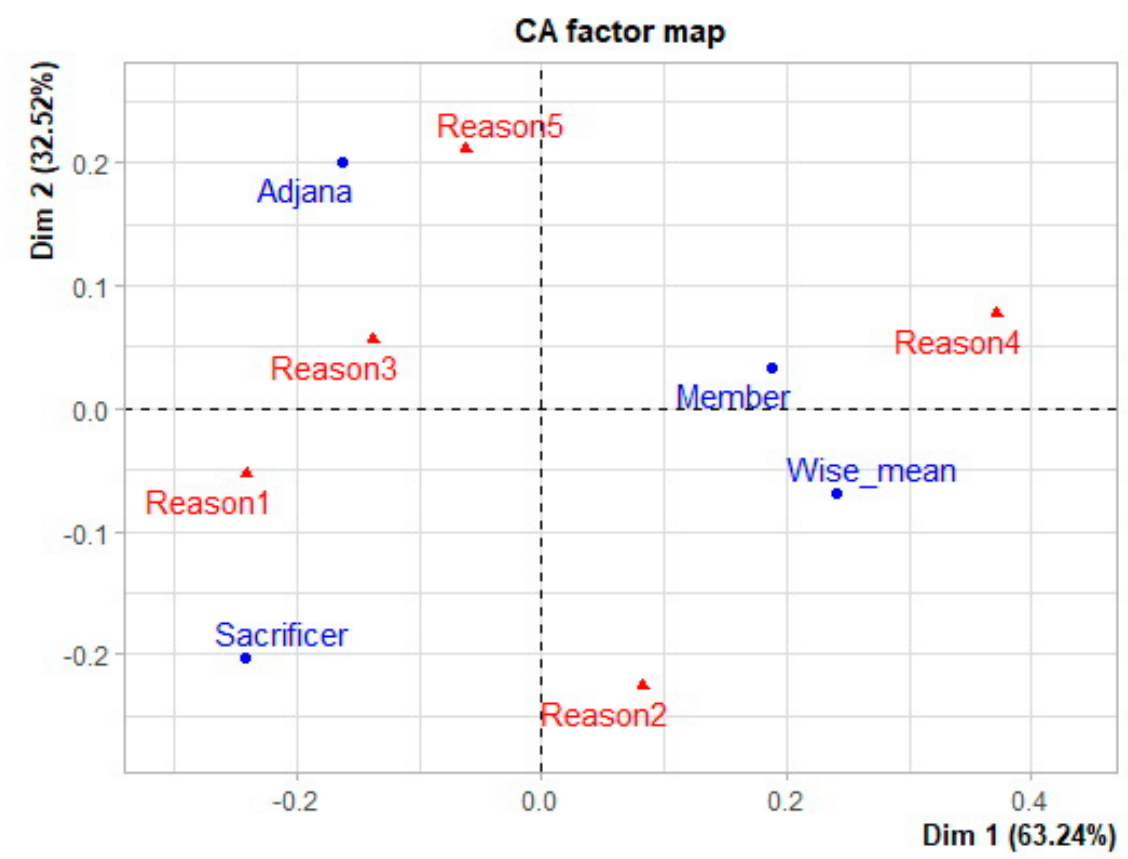

Figure 6. Projection of reasons for irreplaceability of T. scleroxylon in Oro cult ceremonies on factorial axes 
Cultural keystone status score of T. scleroxylon

The Principal Component Analysis (PCA) performed on the predictors of the cultural keystone status of $T$. scleroxylon according to the organs of the species showed that the first two principal components synthesize almost all the information collected (92.2\%; Fig. 7).

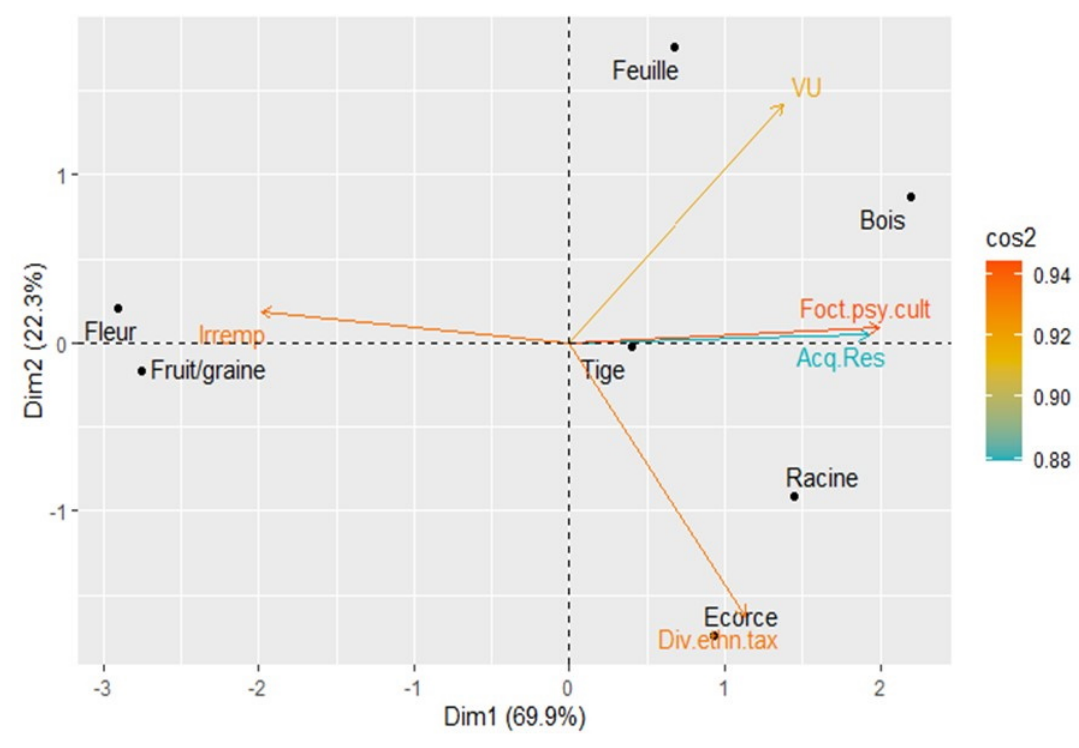

Figure 7. Projection of predictive indices of key cultural vault status and organs of $T$. scleroxylon onto principal components. Legend: $\mathrm{VU}=$ use value, Acq.Res = Resource acquisition, Foct.Psy.Cult = Psycho-socio-cultural function of the species, Div.Ethn.tax = Ethno-taxonomic diversity, Irremp = Irremplaçability.

Values of the cultural keystone scores of T. scleroxylon from the Oro cult in Benin ranged from 0 to 11.53 (Table 4). Bark, roots, stem and wood of T. scleroxylon are parts with the highest cultural keystone scores. Bark, roots, stem and wood are therefore the most important parts contributing to the status of cultural keystone species of $T$. scleroxylon to the Oro cult in Benin.

Table 4. Cultural keystone score of T. scleroxylon

\begin{tabular}{|l|l|l|l|l|l|l|l|}
\hline $\begin{array}{l}\text { Organ from T. } \\
\text { scleroxylon }\end{array}$ & Wood & Bark & Leaf & Flower & Fruit/seed & Root & Stem \\
\hline $\begin{array}{l}\text { Cultural Keystone } \\
\text { Score }\end{array}$ & 3.92 & 11.53 & 0.24 & 0 & 0 & 9.99 & 5.05 \\
\hline
\end{tabular}

\section{Correlation of cultural keystone species indices with cultural keystone status scores}

Fig. 8 presents the Spearman correlation of key cultural species predictors and cultural keystone scores on $T$. scleroxylon in Benin. The results show that irreplaceability and ethno-taxonomic diversity are strongly correlated with the cultural keystone score of the species. The irreplaceability index and the ethno-taxonomic diversity index are thus the indicators that significantly predict the cultural keystone status of T. scleroxylon in Benin.

\section{Discussion}

Results of this study highlighted T. scleroxylon as a cultural keystone species of the Oro cult in Benin

\section{Physical presence}

The first criterion considers that a key cultural species is physically present in the environment of the community under consideration. T. scleroxylon is a revered and sacred Orotree in the Nagot cultural era in Benin. The presence of the species in a habitat is often an indicator of the sacred status of that place. In the Nagot homeland in Benin, there is no sacred forest of the Oro cult without the presence of at least one mature individual of $T$. scleroxylon. 


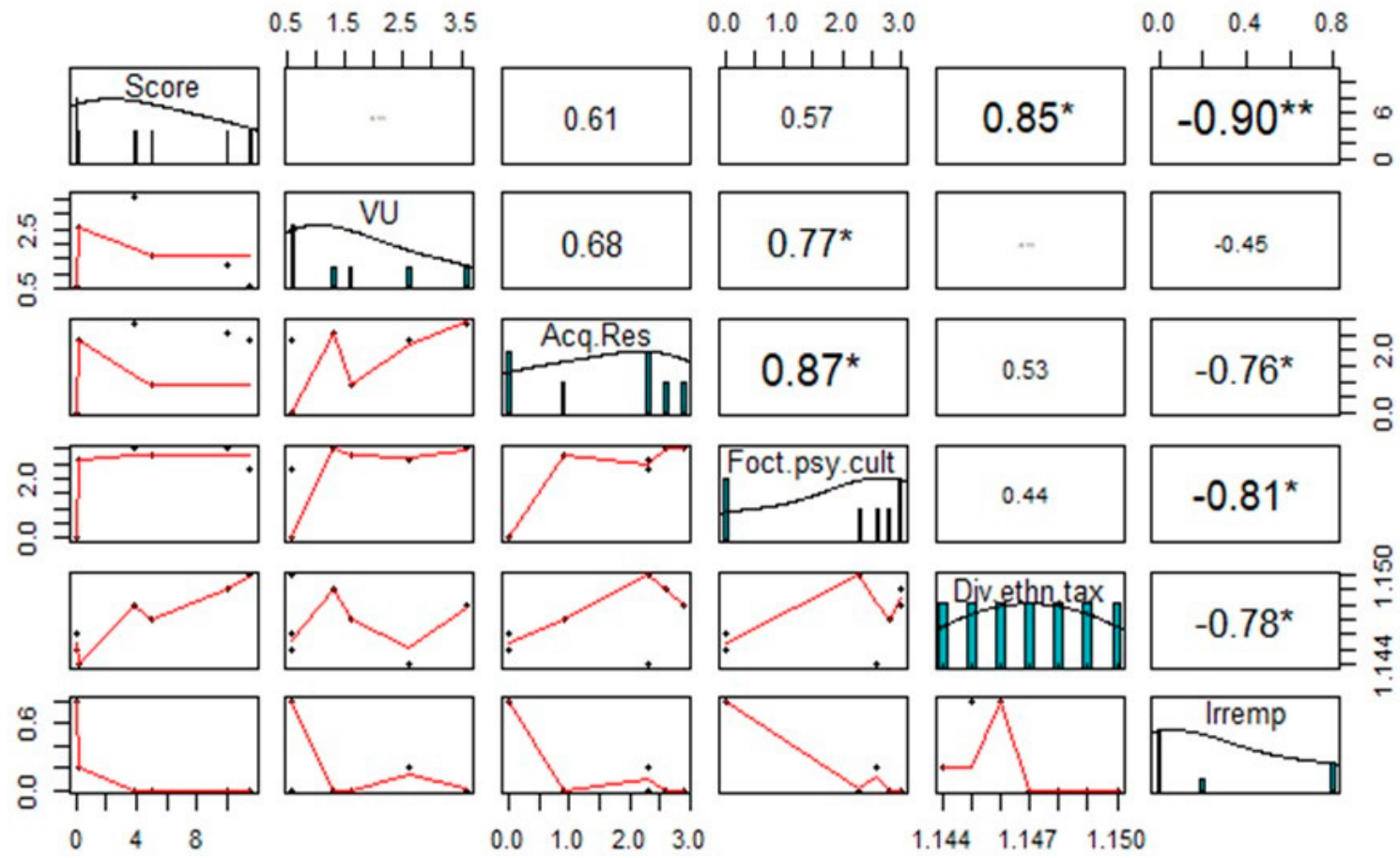

Figure 8. Scatter plot of matrices. Legend: VU = use value, Acq.Res = Resource acquisition, Foct.Psy.Cult $=$ Psychosocio-cultural function of the species, Div.Ethn.tax = Ethno-taxonomic diversity, Irremp = Irremplaçability.

\section{High use value and cultural importance}

The second criterion for designation as a cultural keystone is the use value and cultural importance of the species. The results showing 10 specific uses of $T$. scleroxylon in cultural and/or cultic manifestations of the Oro cult, illustrate the diversity of uses of T. scleroxylon. Beyond the cultural and cultic uses of the species, it represents an additional source of income for the community, thanks to the quality of its wood and medicinal uses. The variation in the level of knowledge obtained among informants may be related to the respondents' rank in the secret societies of Oro. As it is the case in most patriarchal secret societies in African traditions, the level of traditional knowledge about the cult is highly correlated with hierarchy. The knowledge and degree of knowledge about $T$. scleroxylon depends on the level of the informant in the Oro tradition. Use values and versatility of species are good indicators of their cultural importance. But they cannot alone help identify key cultural species especially in regions were a great number of species have high use values (eg. Africa).

\section{Ethno-taxonomic diversity of names}

The different local names given to T. scleroxylon by the actors of the Oro cult testify to the ethno-taxonomic diversity of the names of the species in the Oro cult tradition. The local name of a species being a revelation of a given tradition (Assogba et al. 2017), each of these specific names "Aréré, Egui aréré, Egui ogù and Egui Oro" and the secret names of the different organs in the convents indicate a distant contact and tradition with the Oro. For example, Egui Oro recalls not only that T. scleroxylon symbolizes the Oro but also the mechanisms of the Oro's birth or its revelation to the community. Egui aréré, which means the tree of the dominant stage of the forest, is the tree that receives the first energy from the wind (the energy of the Oro). Although the ethno-taxonomic diversity of the names of a species in a community reveals a distant contact and/or tradition of the species in the history of that community, it cannot alone objectively predict the cultural vault key status of a species. Indeed, it is plausible that the ethno-taxonomic diversity of the names of a species is related to the diversity of use of the species for each group in the community.

\section{Psycho-socio-cultural function of the species}

The use of this indicator to designate a species as a keystone is however relative, as any species that is culturally important to a community can disappear without the community becoming culturally fragmented and unstable. Relying on the psycho-socio-cultural function of species in a system to define cultural keystone status may lead to biased conclusions as the memory of a culture is not static; it evolves over time and is influenced by many different factors (Olick \& Robbins, 1998). 


\section{Unique position of the species}

Triplochiton scleroxylon is an irreplaceable species in some important ceremonies of the Oro cult. This irreplaceability of the species is due to the unique role certain organs such as the root, bark, stem and wood play in the ceremonies and rituals of the Oro cult. The reasons for the unique role of the species in the Orocult tradition vary according to the followers of this tradition. The unique position of the species in the traditional ceremonies of the Oro cult makes it a major species in the preservation and stability of the Oro cult because the sacredness associated with the Oro cult is historically and intimately linked to the species. For the actors of this tradition, "It is the sacred Oro tree". The unique position of a species could be the main index that can predict with certainty its cultural key stone status because key cultural species of a community, are culturally salient species to the extent that their disappearance can have a negatively affect the identity and cultural stability of the community considered (Garibaldi and Turner, 2004).

\section{Additional sources of income}

The sixth criterion is the ability of the species to acquire external resources. Despite its status as a revered and sacred Oro species, T. scleroxylon is traded for its timber products to generate financial resources for the Oro cult community. Organs of the species such as leaves, roots and bark are also harvested by the followers and sold in markets and traditional pharmacies. This criterion also provided insights into the importance of the species but does not stand alone as a reliable indicator of its keystone status. Several agroforestry species in Africa do have very high economic importance to local people.

Based on its unique position in the cultural manifestations of the Oro cult among the Nagot-Yoruba of Benin, Triplochiton scleroxylon arguably is a key cultural species of the Oro cult. Therefore, it will be interesting to assess the impact of the decline of T. scleroxylon on the identity and stability of the Oro cult in Benin and elsewhere. The key cultural species theory predicts that the disappearance of certain plant or animal species can have negative impacts on the identity and cultural stability of a particular community. The Oro cult is known to have survived in several communities of Yorouba descent brought into America during slavery. This offers a unique opportunity to compare the current practices of Oro cults in these communities to what has been preserved at the origin, in order to see what dimensions have been lost and test the prediction that in the absence of $T$. scleroxylon, the spiritual dimensions of the cult will be lost. It is however already evident that in some of those communities far from their original homelands, the cultural value of Oro is taking precedence over its spiritual backbone. In the context of climate change where many species are predicted to be displaced, it would be useful to infer the potential impact of climate change on the distribution of T. scleroxylon as a proxy analysis of its impact of the identity and stability of the cult Oro. Beyond testing for these hypotheses, species like T. scleroxylon urgently need initiation of conservation actions to prevent their extirpation from remnant habitats and to preserve socio-ecological systems that rely on them. Indeed, according to Gaoue \& Ticktin (2007), the versatility of uses can have a severe impact on the demography of prized species. Taboos and sacralizations are to some extent made to protect key species from over-exploitation and extinction (Colding \& Foke, 1997). However, some rituals when they imply heavy pressures on a given species can have the opposite effect in the long term. Studies on the impact of the prevalence of ritual ceremonies and taboos on the demographic and spatial structure of $T$. scleroxylon stands may thus unfold useful insight to inform conservation strategies.

\section{Conclusion}

This study used a multi-criteria approach to illustrate the status of $T$. scleroxylon as a cultural keystone species in the Oro cult tradition in Benin. The study illustrated the complexity of identifying cultural keystones. Cultures are dynamic and adaptive, the recognition of $T$. scleroxylon as a cultural keystone species may essentially remain within the current cultural and historical context. In the future, the species may no longer meet the specific criteria and thus no longer be considered as such. Although the used indices allow an objective assessment, there is no quantitative threshold for these indicators to assess the level of importance of the designation of key cultural or cult species. Despite the pertinence of the approach used, the concept of key cultural species remains subjective as the verification of the theory of key cultural vault species should be done by closely examining whether the removal of a key cultural species would lead to irreversible perpetuities and consequences for the socio-cultural identity and stability of the community or cult considered. Future prospects on this topic may consider using an experimental device that could actually examine the effect of the total extirpation of $T$. scleroxylon on the stability of the Oro cult. Yorouba-Nago communities that were brought out of Africa (eg. to Latin America) and still practice the Oro cult in certain forms offer a good opportunity for this test. 


\section{Declarations}

Ethical approval and consent to participate: All informants gave informed consent before the interviews.

Data availability: Data are available upon reasonable request.

Conflict of interest: The authors declare that they have no competing interests.

Funding: This work was funded by the National Ministry of Higher Education (Ministère de l'Enseignement Supérieur et de la Recherche Scientifique, Bénin) and additional support from the second author.

Authors' contributions: The two authors conceptualized the subject and designed the methodology. The first author conducted the field data collection, statistical analyses of the data and drafted the manuscript. The second authors refined the data processing approach, red and corrected the manuscript. Both authors read and approved the final version of the manuscript.

\section{Acknowledgements}

The authors thank all the Oro cult followers in Benin for their frank collaboration and sense of sharing, the National Ministry of Higher Education of Benin, the field guide Ayéfèmi Kabirou, Mr Akpovo V. H. Abel, Mr Dossou A. Jacques and Mrs Sinsin B.L. Corine for the fruitful exchanges.

\section{Literature cited}

Adomou CA. 2005. Vegetation patterns and environmental gradients in Benin. Implications for biogeography and conservation. Phd thesis, Wageningen University, Wageningen, The Netherlands. https://library.wur.nl/WebQuery/wurpubs/fulltext/121707

Adomou CA., Agbani OP, Sinsin B, 2011. Plants. In: Neuenschwander P, Sinsin B, Goergen G, (éds.). Nature Conservation in West Africa: Red List for Benin. International Institute of Tropical Agriculture, Benin 21-46.

Akanji OR, Dada OMO, 2012. Oro cult: the traditional way of political administration, judiciary system and religious cleansing among the pre-colonial Yoruba natives of Nigeria. The Journal of International Social Research 23(5):1926.

Akouègninou A. 1998. Les forêts denses humides semi-décidues du Sud-Bénin. Journal de la Recherche Scientifique de l'Université du Bénin 2(1):125-131.

Assogba GA, Fandohan AB, Salako VK, Assogbadjo AE. 2017. Usages de Bombax costatum (Malvaceae) dans les terroirs riverains de la Réserve de biosphère de la Pendjari, République du Bénin. Bois et Forêts des Tropiques, 333(3) :17-29. doi: 10.19182/bft2017.333.a31465

Berkers F. 2002. Epilogue: making sense of Arctic environmental change? In Krupnik I, Jolly D. (eds). The earth is faster now. indigenous observations of Arctic environmental change. Arctic Research Consortium of the United States, Fairbanks, Alaska, USA.

Ceperley N, Montagnini F, Natta A. 2010. Significance of sacred sites for riparian forest conservation in Central Benin. Bois et Forêts des Tropiques 303(1):5-23.

Coe MA, Gaoue OG. 2020. Cultural Importance Indices Do Not Predict Species' Cultural Keystone Status. Human Ecology doi: 10.1007/s10745-020-00192-y

Coe MA, Gaoue OG. 2020. Cultural keystone species revisited: are we asking the right questions? Journal of Ethnobiology and Ethnomedicine. doi: 10.1186/s13002-020-00422-z

Colding J, Folke C. 1997. The relations among threatened species, their protection, and taboos. Conservation Ecology 1(1):6. http://www.consecol.org/vol1/iss1/art6/

Cristancho S, Vining J. 2004. Culturally defined keystone species. Human Ecology Revew 11:153-164.

Fairhead J, Leach M. 1998. Réexamen de l'étendue de la déforestation en Afrique de l'Ouest au XXè siècle. Unasylva 192(49):38-46.

Gaoué OG, Ticktin T. 2007. Patterns of harvesting foliage and bark from the multipurpose tree Khaya senegalensis in Benin: variation across ecological regions and its impacts one population structure. Biological Conservation, 137, pp.424-436.

Gaoue OG, Coe MA, Bond M, Hart G, Seyler BC, McMillen H. 2017. Theories and major hypotheses in ethnobotany. Economic Botany 1-19

Garibaldi A, Turner N. 2004. Cultural keystone species: Implications for ecological conservation and restoration. Ecology and Society 9(3). https://www.ecologyandsociety.org/vol9/iss3/art1/ 
Gomez-Beloz A. 2002. Plant use knowledge of the Winikina Warao: The case for questionnaires in ethnobotany. Economic Botan 56:231-241.

Gouwakinnou GN, Lykkey AM, Assogbadjo AE, Sinsin B. 2011. Local knowledge, pattern and diversity of use of Sclerocarya birrea. Journal of Ethnobiology and Ethnomedicine 7:8. doi: 10.1186/1746-4269-7-8

International Society of Ethnobiology. ISE Code of Ethics (With 2008 additions). 2008. http//ethnobiology.net/codeof-ethics/code-in-english/.

Kassambara A, Mundt F. 2020. Factoextra: Extract and Visualize the results of Multivariate Data Analyses. R package version 1.0.7. https://CRAN.Rproject.org/package=factoextra.

Kokou K, Sokpon N. 2006. Les forêts sacrées du couloir de Dahomey. Bois et Forêt des Tropiques 288(2 :15-23. file:///C:/Users/HP/Downloads/20312-Texte\%20de\%20l'article-20464-1-10-20150728.pdf

Lê S, Josse J, Mazet F. 2008. Package 'FactoMineR'. Journal of Statistical Software 25(1):1-18.

McCarthy A, Hepburn C, Scott N, Schweikert K, Turner R, Moller H. 2014. Local people see and care most? Severe depletion of inshore fishore and its consequences for Maori communities in New Zealand. Aquatic Conservation: Marine and Freshwater Ecosystems, 24(3): 369-390.

Olick JK, Robbins J, 1998. Social memory studies. From "collective memory" to the historical sociology of mnemonic pratices. Annual Review of Sociology 24:105-140. doi: 10.1146/annurev.soc.24.1.105

Palla F, Louppe D. 2002. Obeché. CIRAD, Montpellier, pp. 6. https://agritrop.cirad.fr/515653/1/document_515653.pdf

Salzmann U, Hoelzmann P. 2005. The Dahomey Gap: an abrupt climatically induced rain forest fragmentation in West Africa during the late Holocene. The Holocene 15(2):190-199. doi: 10.1191/0959683605hl799rp

Sujarwo W, Caneva G, Zuccarello V. 2019. Bio-cultural traits and cultural keystone species, a combined approach: an example of application about plants used for food and nutraceutical purposes in Aga villages in Bali, Indonesia. Human Ecology 47(6):917-929.

TRAMIL, 1989. Vers une pharmacopée aux Caraïbes (TRAMIL4). enda-Carabe, Université Nationale Autonome du Honduras (UNAH). Tegucilpa, Honduras. 475p.

Turner NJ. 1973. The ethnobotany of Belle Coola Indians of British Columbia. Economic Botany 25(1):63-104. 